\title{
A Single Man in a Complex Movie - or - Tom Ford Between Sketch Block and Screen
}

\author{
Silke Roesler-Keilholz \\ University of Regensburg, Regensburg, Germany
}

\begin{abstract}
"I love suits! One feels so save and kept together in it. Like in an armour!" (von Taube, 2008, p. 1). This remark by designer Tom Ford in a newspaper article a couple of years ago finds expression in the behaviour of George Falconer (Colin Firth) - the main protagonist in Ford's directorial debut A Single Man (2010) which follows the outlines of the landmark 1964 novel of the same title by Christopher Isherwood. In this article the author want to ask questions concerning the different aesthetic potentials of the novel on the one hand and the movie on the other hand. How are the main topics of loss and solitude presented and which relevance has the beauty of the image in these two different staging acts?
\end{abstract}

Keywords: Loss, solitude, aesthetic, novel and film adaption

"I love suits! One feels so save and kept together in it. Like in an armour!" (von Taube, 2008, p. 1). This remark by Tom Ford finds expression in the behaviour of George Falconer-the main protagonist in Ford's directorial debut $A$ Single Man (2010) which follows the outlines of the landmark 1964 novel of the same title by Christopher Isherwood. To get ready for the day the university professor George puts on his clothes, his personal armour (Devoucoux, 2007, p. 103), in his apartment full of geometric forms and beauty. His beloved partner Jim was killed by a car accident eight months ago. Right at the beginning of the novel it says: "By the time it has gotten dressed, it has become he; has become already more or less George-though still not the whole George they demand and are prepared to recognize" (Isherwood, 1991 [1964], p. 3). In Ford's film we watch George routinely shaving himself, assuredly taking some pills, precisely putting on eau de toilette, carefully cleaning his shoes and diligently straightening his tie (see Figure 1). All these actions seem to be related to the wish to order the universe in some way. The camera captures every single of George's moves in an efficient flow and presents the actions as if they would anchor him in life. He obviously needs this daily ritual to play his role in life, to "behave" as good as he is able to. His suit forms the physic "frontier between self and the not-self" (Wilson, 2003, p. 2) in this arrangement. But behind the façade George is a broken man. The reader of the novel and the movie spectator both now follow a day of George's life. Ostensible it is an average day on which he teaches a lesson about Aldous Huxley and meets different people. But all of these experiences, thoughts, and emotions are shadowed by the loss of his partner.

It is no easy material which Ford, the former chef designer of Gucci and Yves Saint Laurent now leading his own brand, has chosen for his first movie. Reviews differ between terms of a visual masterpiece and an overloaded visual experience which would not justice to Isherwood's complex narration. Because of this wide

Silke Roesler-Keilholz, Dr. phil., Media Studies Department, University of Regensburg. 
span of comments the author will have a closer look on the film by working out the potentials which lie in between the comparison of the two different art forms (novel and movie). The author will try to find answers to the questions how and why Ford's debut can be viewed as a brilliant oeuvre on its own. To verify this assumption, the author will go on analyzing different sequences of the movie: Some of them find very similar pictures for what Isherwood describes in his novel. In another scene Ford creates sensitive and enriching extensions as well as modifications of the written word, and furthermore some sequences have no counterpart in the original. This analysis shall be bound back to the overall questions: How are the main topics of loss and solitude presented and which relevance has the beauty of the image, the montage and miseen scène especially for the story of single man George Falconer in Ford's film?

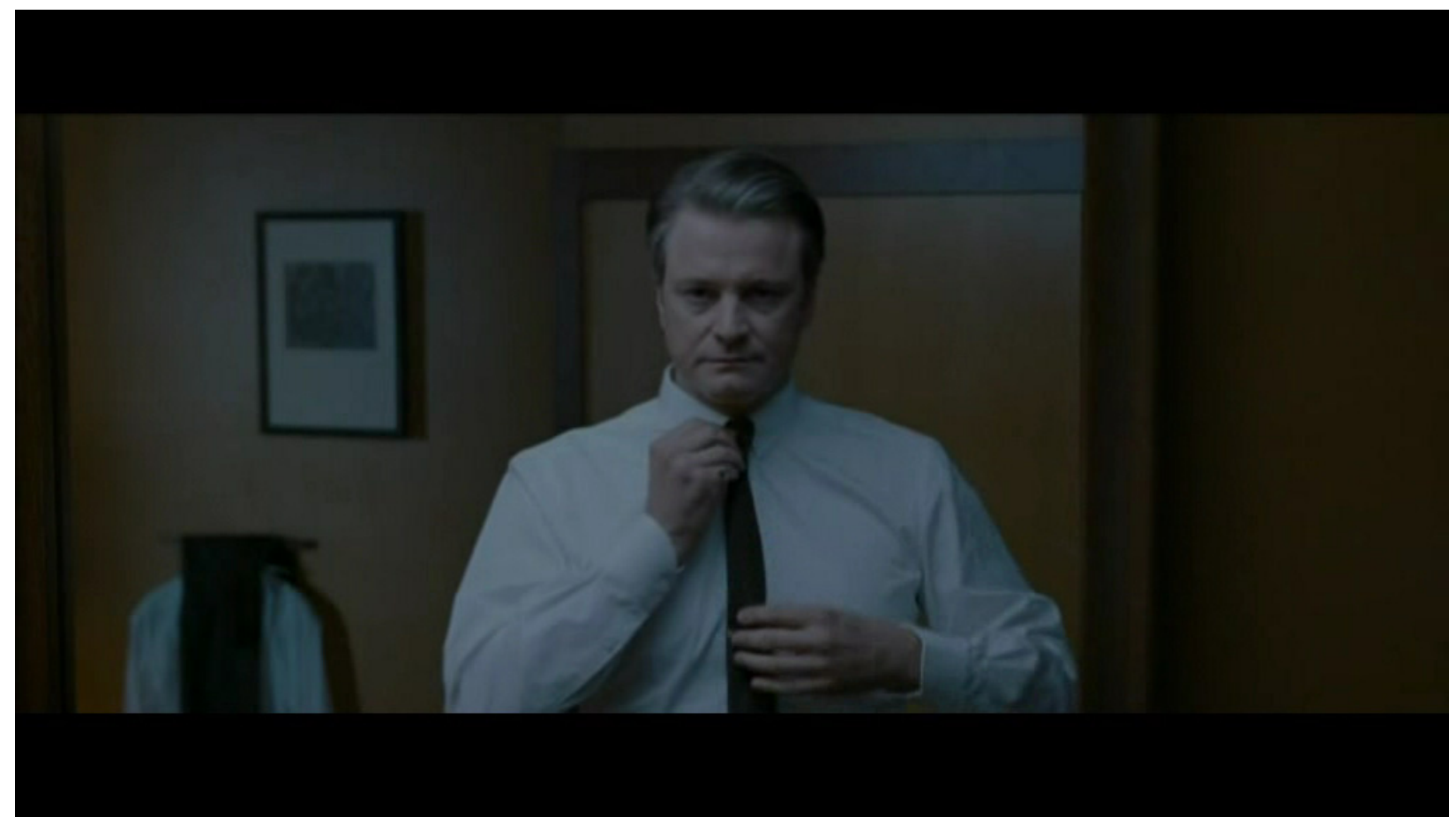

Figure 1. A Singe Man (John Ford, USA, 2009).

But let me shortly contextualise Isherwood's novel at first: Isherwood's life and writing are often seen in two conveniently defined halves (Berg, 2005): one English, the other American. The early, English part of Isherwood's oeuvre forms the basis for conventional appraisals of his work. The novel Goodbye to Berlin (1939), a loose collection of stories and sketches, provided the source material for Cabaret, the musical play (1966) and film (1972). The later, American, half is gaining recognition for its groundbreaking openness in the treatment of homosexuality. The novel A Single Man (1964) is seen by many, especially in the United States, as a masterpiece of characterization, style and precision. It was Isherwood's favourite of his nine novels, the one in which he believed he had come closest to saying what he meant to say. More recently, American author Edmund White has hailed $A$ Single Man as the founding text of modern gay literature. Isherwood himself had lots of affairs and was in the middle of a life and work crisis when he met the just 18 -year-old Don Bachardy in February 1954. Against all odds and accompanied by many ups and downs they stayed together for 33 years till Isherwood died because of cancer in 1986. Isherwood and Bachardy were one of the first public homosexual couples and they took part at the first gay-pride-parades in the 1970s. It has often been mentioned 
that the relationship to Bachardy has influenced Isherwood's life and thoughts in an intense way. Especially the writer's fear of loss of a beloved person shall be rooted in his private life with the young artist Bachardy. Having this in mind single man George Falconer is in parts the object of projection of Isherwood's fear and doubts.

George is living alone since the death of his lover and he nurses resentment against a society that considers him, a gay man, to be "unspeakable", a "monster" (Isherwood, 1991[1964], p. 10). And though the topic of solitude is not constantly central to the novel - definitely more explicit in the movie as we will see-, the loss of Jim is always there, looming over George, haunting his every step. Isherwood masterfully captures an ambience of loneliness and emptiness and longing throughout the text; the prose and George's thoughts are sparse and detached. To the protagonist a post-Jim world, every day has become mundane, and every action routine. The professor nevertheless is a man who is going through the motions without knowing why. George interacts with several individuals throughout the course of his day, and yet is frustrated with most of them - they just don't seem "to getit". He feels isolated and disconnected from everything and everyone he knows. He seems to yearn to understand, to crave so desperately that connection with another that makes us human. And yet, time and time again, he fails. George's detachment from life and from others taps into deep, universal human emotion, and as much as he pushes others away, it is painfully evident that George wants so badly for them to understand. But Isherwood's George is, after all, a single man.

\section{Similarities}

The first sequence of the movie the author want to point to is when George converses with his colleague besides a tennis court where athletic, sweaty young men are playing. As George steals glances at the players, "the conversation slowly fades out and the thumping of heartbeats is all we hear" (Wang, 2010). In matching imagery are close-ups of bare chests, gleaming muscles, and sweaty, touchable parts: lips, eyes, the hollow above the collarbone, an arched back, all cut in rapid flashes to the rhythm of the heartbeats (Wang, 2010) (see Figure 2). By the montage of the different takes, the driven combination of shots, the movie spectator becomes "sutured" with George. It is almost as if we were in George's head and as if his thoughts have materialized into cinematography. The pictures become more and more orange and appear extremely vivid and emotional. There is nothing said, and "George doesn't give away a single lustful glance, but the desire hangs thickly in this scene" (Wang, 2010). Accordingly, it says in the novel:

They are passing the tennis courts, at this moment. Only one court is occupied, by two young men playing singles. The sun has come out with sudden fierce heat through the smog-haze. And the two are stripped nearly naked. They have nothing on their bodies but rubber gym-boots and knit shorts of the kind cyclists wear, very short and close-fitting, moulding themselves to the buttocks and the loins. [...] You would think there was no net between them. Their nakedness makes them seem close to each other and directly opposed, body to body, like fighters. [...] And they will never know what they have done to make this moment marvellous to him, and life itself less hateful. (Isherwood, 1991 [1964], p. 37)

Novel and movie both stress George's attraction towards the two young men. For what Isherwood describes in meaningful words, Ford and cinematographer Eduard Grau find colourful pictures. Maybe this moment of plot is one of the most sexualized in both - novel and film. George's glance at the boys implies some voyeuristic potential, which is always rooted in a sexual interest. Maybe one could say that the mentioned sequence mirrors very few minutes in George's life where he is able to "feel", to enjoy the interest in and lust 
for people. Emotions that contrast his other structured and organized life which is dominated by feelings of deafness, solitude and loss.

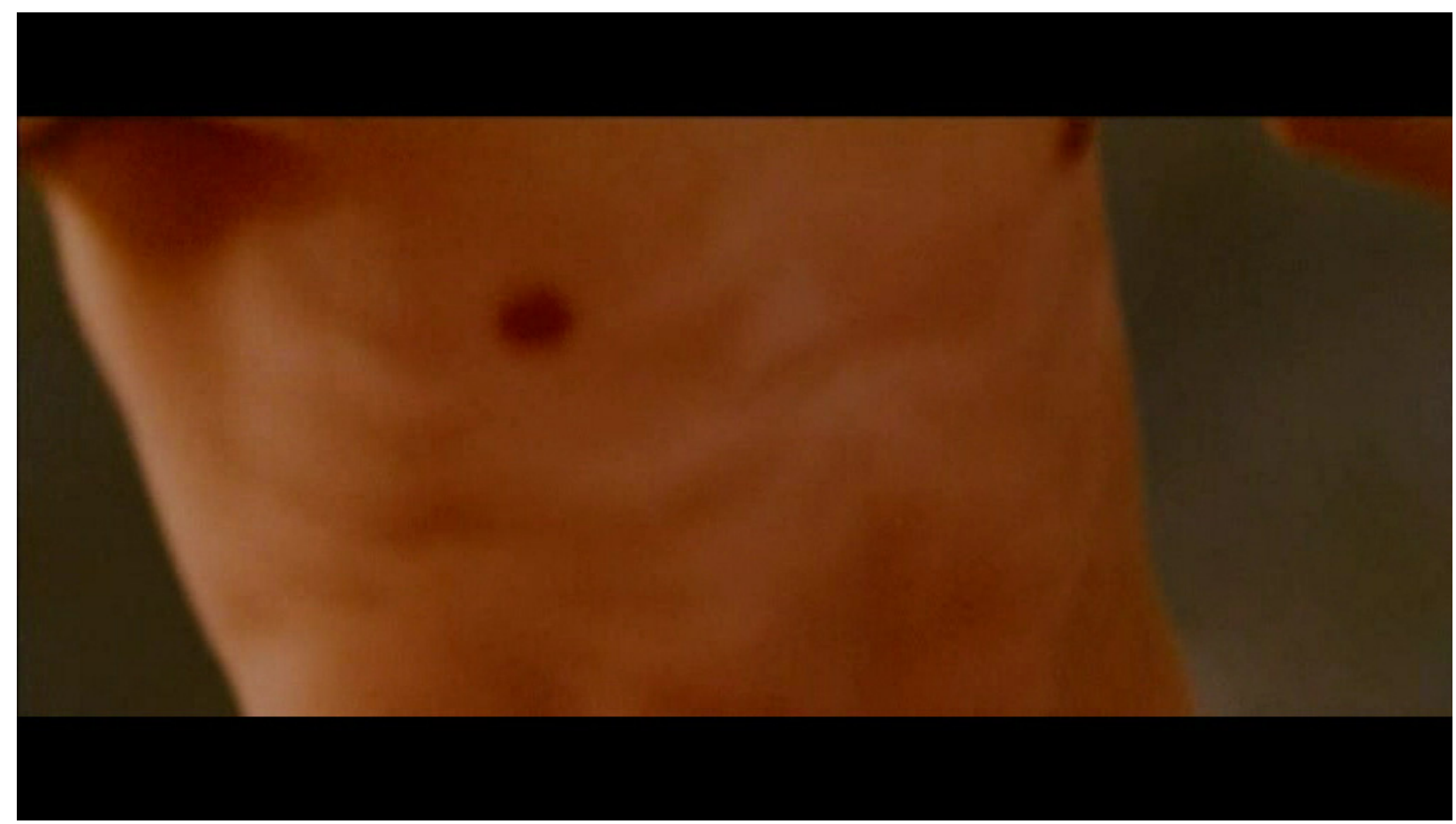

Figure 2. A Singe Man (John Ford, USA, 2009).

Also the encounters between George and his student Kenny (Nicholas Hoult) — the walk on the campus, a talk at a bar at night-time and a kind of moonlight swimming in the ocean - resemble pretty much Isherwood's oeuvre. Likewise to the tennis-sequence these scenes are also presented very colourful and opulent. After having a couple of drinks and a nightly conversation about life - the colouring of the images during this talk also changes between orange and red-George and Kenny decide to have a bath in the pacific. Like boisterous teenagers they run to the beach, get naked, jump into the water and foul around. The night is dark, the ocean's waves are almost as black as the ceiling and they seem to gorge the two men. The string players' play of Abel Korzeniowski's fantastic score gets faster and faster and seems to mirror the arousal of the two men. Accordingly it says in the novel: "He [SR: George] is perfectly happy by himself; it's enough to know that Kenny and he are the sole sharers of the element. The waves and the night and the noise exist only for their play" (Isherwood, 1991 [1964], p. 132). Again, George is able to re-live moments of joy. But as it says in the novel: It is just a "play" what he experiences in this moment, it is not the real life which still is a life without Jim.

\section{Extensions}

And then, there is Charley (Julianne Moore):

Gorgeous, lush, drunk Charley, who gains more space in Ford's debut than in the original. Julianne Moore, again, presents another façade of her enormous span in acting. She definitely enriches Ford's movie by her multifaceted play between a beautiful woman, a former diva, a forsaken woman and a dear friend. She and George are old friends, both from London, who shared a brief and distant history as lovers. He calls her kiddo and brings her gin. She arranges an elegant dinner for them in her elegant house, in which the hallway between front door and the living room is lined with orange trees, like a seductive fortress. Charley is emotional and fragile. Once married and now alone, she is trapped in her 
decadent house and no one truly has time for her. Her existence is one of solitude, and we never see her leaving the house. She doesn't even buy her own gin. She is either in bed or meticulously drawing on makeup in front of the vanity, like slipping on a familiar mask. In one brilliant shot we see her face divided, one eye fully made up and the other bare, it's probably the closest we ever get to the real Charley (see Figure 3). Ford offers a fascination look into the relationship between a straight woman and a gay man, especially one that retains more of the traditionally masculine qualities. Talking in a cliché one could say that such a friendship can be very rewarding, since there is no sexual competition and advances. The movie shows the collapse of such a framework or assumption. To Charley, George is everything she ever wanted in a companion, or so she thinks. (Wang, 2010)

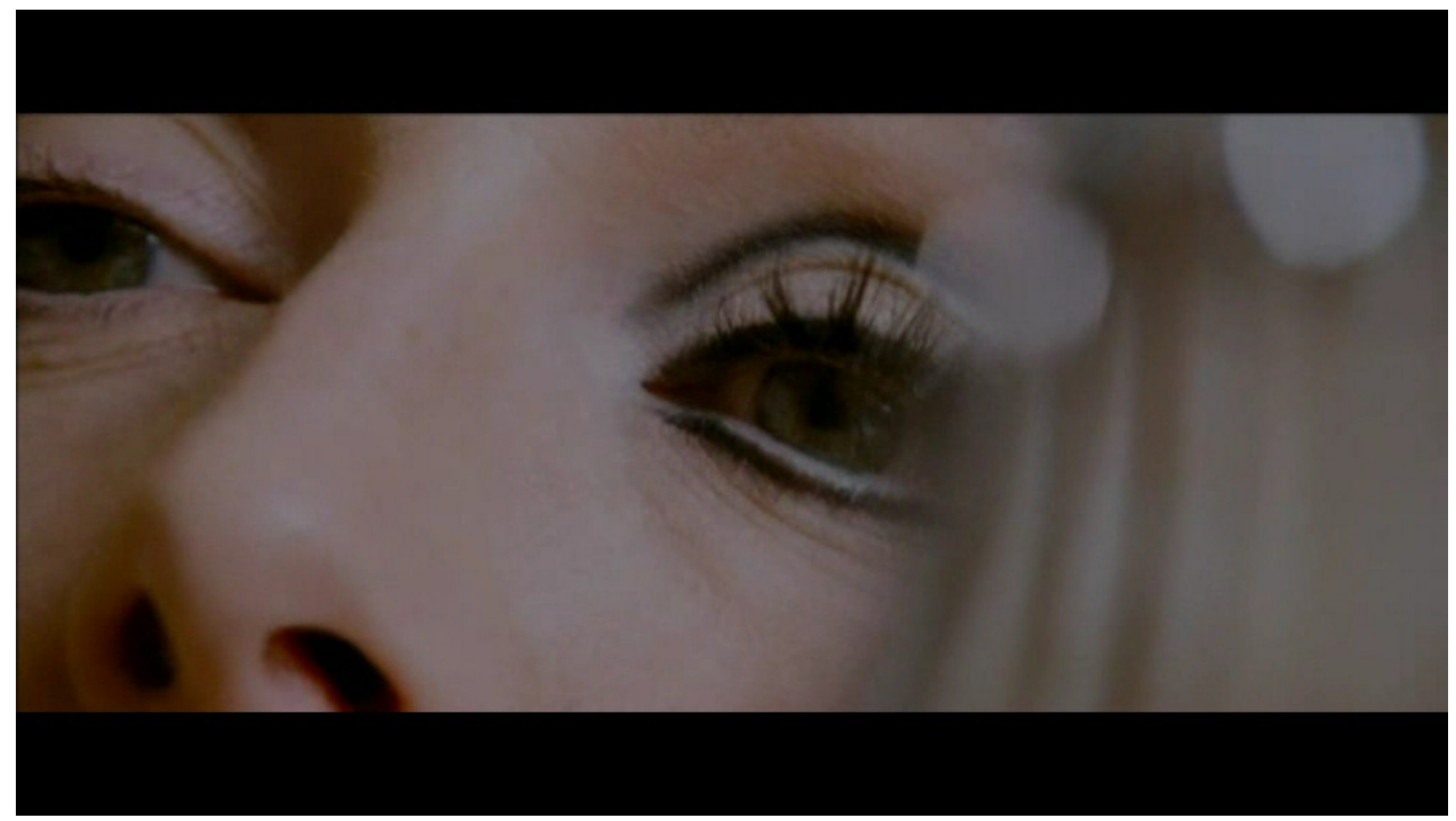

Figure 3. A Singe Man (John Ford, USA, 2009).

Accordingly it says in the novel: "She has been watching for him, as usual, and no doubt fearing some last-moment change in his plans" (Isherwood, 1991 [1964], p. 95)—she obviously is addicted to him. To George, Charley is a dear friend that he once tried to "have a go" with before meeting his true love. But furthermore, on a platonic level, she is his anchor in life. When Jim died, she was his first addressee. Twice, Ford shows us almost the same emphatic and unsettling flashback how George is running to Charley's house at night crying for help and beating at her door. The movie spectator does not hear anything but the pouring rain, we see a crying broken man in Charley's arms.

This night Charley is wearing a beautiful, long, silky, black and white dress, elegant and sexy, reminding of the 1960s op-art-fashion. From the earliest days of cinema, costume was seen as an extension of acting and here Ford definitely created a "perfect match": “[...] a woman's dress and demeanor, much more than a man's, indexes psychology; if costume represents interiority, it is she who is turned inside out on screen" (Gaines, 1990, p. 188). So what does Charley's dress index? After dinner George and Charley have their "private dance". Charley opens the dance by touching George from behind, laying her head on his shoulders, moving her hips. At first they slowly dance to Jetta Jame's soulful "Stormy Weather". Then we watch Charley changing the record to “Green Onions" by Booker T and the MG's - a mod-classic from the 1960s. Instantly we follow George and 
Charley doing the twist. Obviously they have been dancing together since many years. As if they were just having sex, after the dance they both lay down on the floor, exhausted, and George lightens up two pink cigarettes, one for each of them. George and Charley are soul-mates, and maybe this relationship is even stronger than a sexual one. But paradoxically, at the same time they are two lonely souls that long to be connected, to someone, somehow, in some meaningful way. They both love someone who is not reachable: Charley loves George, George loves Jim.

\section{Enhancements}

On his way home from school George steps by a liquor store to buy some Gin for Charley. Leaving the store he runs into the Spanish James Dean look-alike Carlos (Jon Kortajarena)-a scene which has no counterpart in the novel. While the two of them are having a flirt the camera partly frames George's encounter with the hustler in front of a billboard for Alfred Hitchcock's Psycho featuring a wild-eyed Janet Leigh evoking the unsettlingly sexual menace of Psycho. While chatting about life in Spain, in Los Angeles and in general, Ford cuts in between close-ups of Carlos, how he lays back his head, how he opens is mouth, all of them impressions of an aroused man (see Figure 4). The images have almost turned from orange into red and can be taken as distinct references to sexual excitement. Happiness, again in my opinion perceptible in these shots, definitely is not the pervasive tone of Ford's movie, but rather a contrast tool that is preserved in reveries and dotted sparsely in between the dreary monotone shots of George's life (Wang, 2010). Ford evocates these encounters brilliantly with colours. The palette shifts from drab neutrals into warmer, fresher shades of blues, yellows, and pinks. It's almost as if these encounters actually physically brighten up George's day. The colours pull George's eyes and ours into focus, and in a way energize the film, and George's day, making his impending choice that much more precarious. In my opinion, Ford is excellent in engaging all our senses to feel that of George's. His creative control is absolute, and there is an undeniable confidence in the precise way he uses camera angles, colours, and sound to evoke the intangible anguish and desperation that boils within George.

Also the intermittent flashbacks of life with Jim (Matthew Goode), as well as the film opening and ending differ from the novel. The film opens with an image of George slowly sinking naked in water, a vision suggestive of rebirth and fatal submersion. This is immediately followed by a starkly different image of him slowly entering, as if in trance, a disquieting tableau in which Jim and a terrier lie dead in a snowy field next to a wrecked automobile and a large, vivid blot of blood (Dargis, 2009). Carefully, George lowers himself next to his dead lover and tenderly kisses his mouth, a gesture that seems to cause George — who had actually been sleeping and presumably dreaming — to wake in his bed.

Right from the beginning the plot is accompanied by Abel Korzeniowski's sentimental, intense, and opulent score. At times the string players sound as they would struggle with life, at times as if they would cry. The sound carpet follows most of George's steps during the day. In flashbacks we see bits and pieces of George's and Jim's life together, one of aged banter and joyful companionship. In one scene they sit together on the sofa and read, separately, facing each other, legs tucked up and intertwined, a puppy snuggling lazily besides them. They speak of nothing in particular, make fun of each other's books, and banter over whose turn it is to change the music. They look at each other-long, unabashed glances, as if there was a more complex definition of happiness. (Dargis, 2009)

At one point Georges buys some bullets. During the whole day we watch George planning his suicide, arranging some things (like choosing a proper suit for his funeral, putting the different keys to the doors on a table and depositing some money for the maid. Ford, who shares screenwriting credit with David Scearce, introduces a 
gun maybe because the novel has too little obvious dramatic tension. In one brilliant scene we observe George how he tries to kill himself. He covers himself in a sleeping bag because he does not want to make a mess by firing the bullet into his head. By staging this scene Ford shows in a slightly sarcastic manor in which way George has become a victim of his own perfectionism and desire of beauty. In the end his suicide attempt is interrupted by a call from Charley. Her call for gin saves George's life for the present.

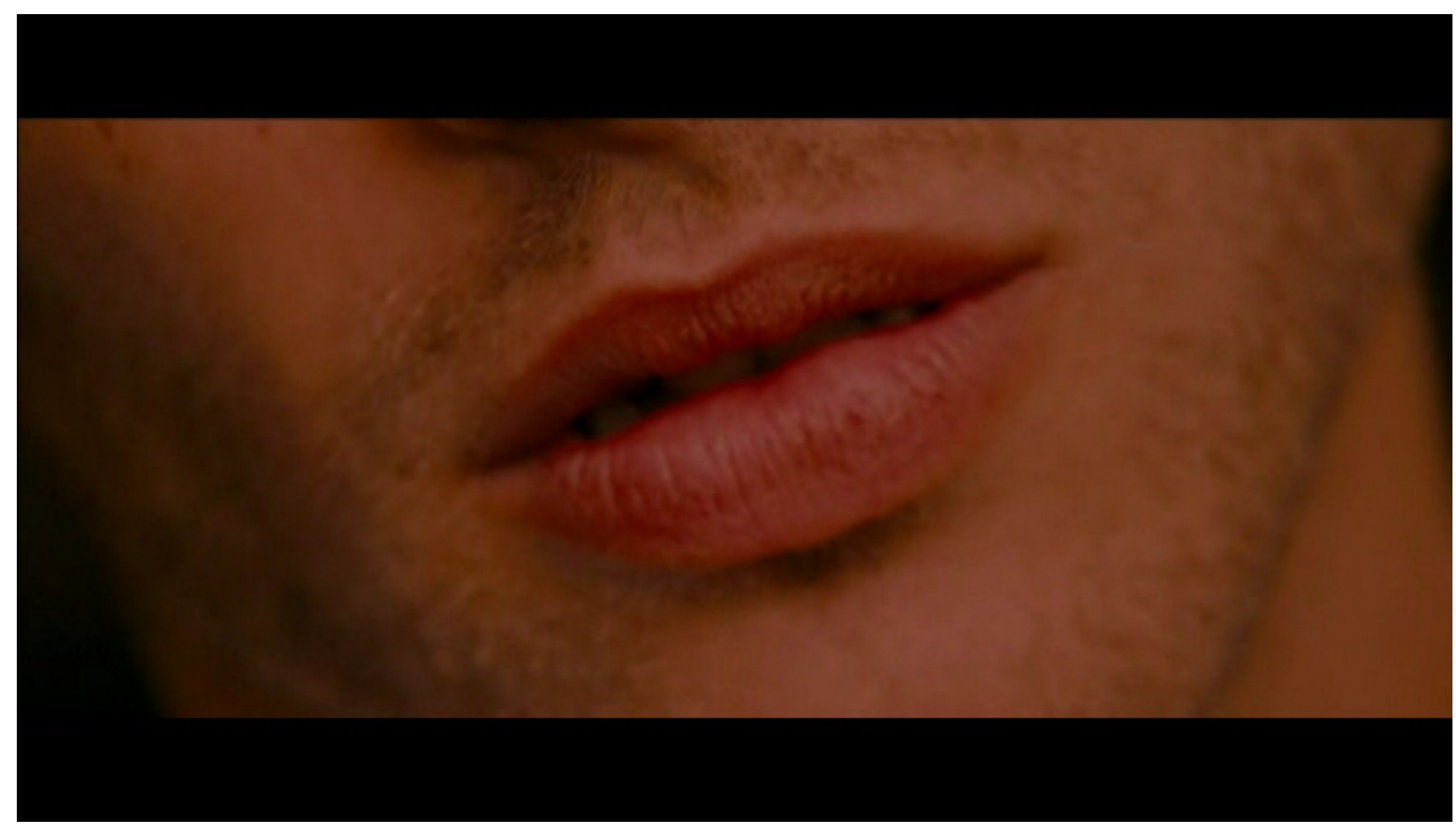

Figure 4. A Singe Man (John Ford, USA, 2009).

\section{Conclusion of Paradoxes}

Of course - furthermore - there are many aspects, details and even plot lines which the novel presents (like George visiting a friend at a hospital or his insistent monologue about urbanity and the American Zeitgeist) which the film does not put into focus. Nevertheless it was my aim to stress the potentials of the audio-visual medium film, which are obvious in multi-dimensional and gleaming facets in A Single Man. Every single frame of Ford's movie could be mistaken for a postcard, and even as pure eye candy it succeeds. But, fortunately, it is much more than that (Wang, 2010). The beauty of Ford's pictures are not only embellishments, they contribute to the plot in a way that the movie finds pictures for emotions, subtexts and details. Ford's A Single Man is an important contribution to the topic and negotiation of loss in film, which dominates the US-American cinema since many years (Keilholz, 2009). Almost every picture in the movie, especially the beautiful and colourful ones, evoke a feeling of loss and sorrow. In those moments when George is able to "feel" and to enjoy the situation, he also knows what he has not most of the time, what one can lose and what he has already lost. The feeling of loss and solitude can paradoxically become even more powerful and hurtful in those moments you live and enjoy. By slow motions - for example when George leaves for school and drives by the neighbour's kids (see Figure 5) — or by rapid double cuts Ford seems to expand time, a time which for George has become more and more trivial, or maybe to delay destiny. 


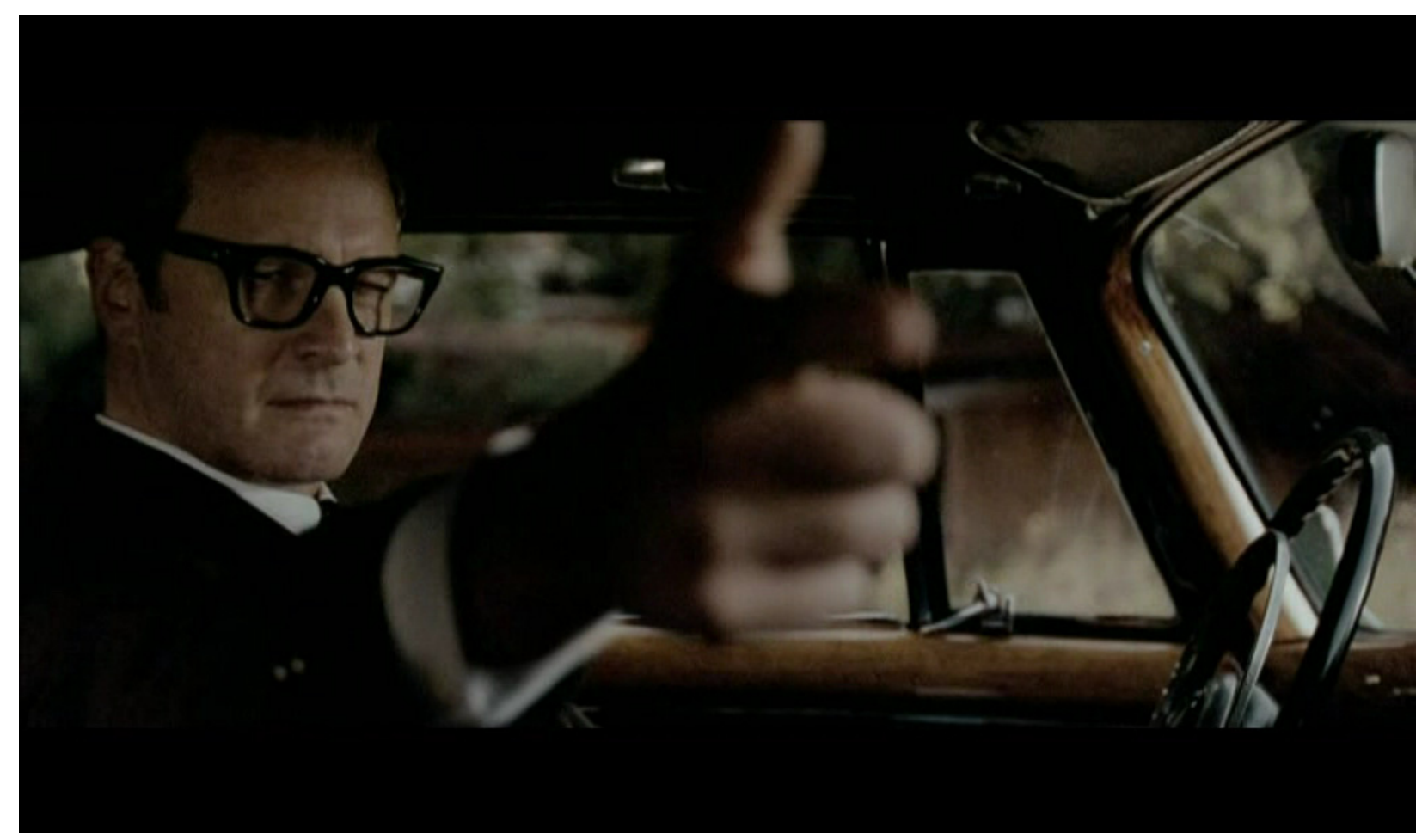

Figure 5. A Singe Man (John Ford, USA, 2009).

Tom Ford's movie is a piece of art on its own. It is even more than a beautiful and brilliant extension of Isherwood's masterpiece. Colin Firth powerfully convinces us of a man who is seething with desperation to break out of the meaningless cocoon that has become of his life, and yet is so socially shackled that he doesn't quite know how to make damage. Julianne Moore is flawless in her brief outburst as a woman in stasis. Definitely Ford's piece is more explicit in the concrete showing of sorrow and the fear of loss than the novel. Just once or twice - when drunk - does George open himself up to another person in Isherwood's piece. Near the end of the novel, George attempts to express to his student Kenny the impossibility of imparting his experience to him, of telling him what he knows. The accumulations of a lifetime cannot be reduced so easily. Accordingly he says: "What I know is what I am" (Isherwood, 1991 [1964], p. 144). In the end though, the novel and the movie broth throw a look on a single man, in a single day, with a single end in mind (Wang, 2010). But it may as well have been any other person on any other day.

\section{References}

Berg, J. (2005). Christopher Isherwood. Retrieved December 2nd, 2016, from http://www.litencyc.com/php/speople.php?rec=true\&UID=2317

Cook, P. (1996). Fashioning the nation: Costume and identity in British cinema. London: BFI Publishing.

Dargis, M. (2009). A love that speaks its name: A college professor's fateful day. Retrieved July 11th, 2010, from http://movies.nytimes.com/2009/12/11/movies/11singleman.html

Devoucoux, D. (2007). Mode im Film: Zur Kulturanthropologie zweier Medien. Bielefeld: Transcript.

Gaines, J. (1990). Costume and narrative: How dress tells the woman's story. In J. Gaines, \& C. Herzog (Eds.), Fabrications: Costume and the female body (pp. 180-211). New York, London: Routledge.

Isherwood, C. (1991 [1964]). A single man. London: Vintage Publishing.

Keilholz, S. (2009). Zerfallstudien: Verlusterfahrungen im Nordamerikanischen Independent Kino 1991-2002. Frankfurt a. M.: Peter Lang. 
Lurie, A. (1992). The language of clothes. London: Bloomsbury.

von Taube, D. (2008). Eigentlich sind wir alle ein Haufen Müll. Retrieved July 11th, 2010, from http://www.welt.de/lifestyle/article1916407/Eigentlich_sind_wir_alle_ein_Haufen_Muell.html

Wang, G. (2010). A single man. Retrieved December 2nd, 2016, from http://etheriel.wordpress.com/2010/02/01/a-single-man/

Wilson, E. (2003). Adorned in dreams, fashion and modernity. New Jersey: Rutgers. 